\title{
Social Skills of Students in The Pandemic Period
}

\section{Prima Retnaning Mareta, Akhmad Arif M, Susanto}

Universitas Sebelas Maret

primaretnaning37@gmail.com

\section{Article History}

accepted 1/09/2020

approved 4/10/2020

published 1/12/2020

\begin{abstract}
The pandemic period which is increasingly protracted and it is not clear when it will end has disrupted all human activities, one of which is learning activities in school. After the physical distancing rules are implemented, student learning activities are carried out at home. This results in students experiencing a decrease in student affective skills, besides that the teacher also experiences limitations in monitoring student affective behavior. Therefore, this study aims to determine the extent to which students' social skills during the pandemic. The research subjects were students of SMA Negeri 1 Kedunggalar, Ngawi Regency, with 76 students as respondents who were randomly selected from various classes, majors, and genders. This research is a qualitative descriptive study. Data collection techniques using a questionnaire. Data analysis in this study refers to an interactive analysis model consisting of the stages of data reduction, data presentation, and data verification. From this research, the goal is to be able to see how the attitude of students' social skills during the pandemic.
\end{abstract}

Keywords: Social skills, students, pandemic

\begin{abstract}
Abstrak
Masa pandemi yang kian berlarut dan belum jelas kapan berakhirnya mengakibatkan semua aktifitas manusia terganggu, salah satunya aktifitas pembelajaran di sekolahan. Setelah dilaksanakan peraturan physical distancing berdampak aktifitas belajar siswa dilaksanakan di rumah. Hal itu mengakibatkan siswa mengalami penurunan ketrampilan afektif siswa, selain itu guru juga mengalami keterbatsan memantau perilaku afektif siswa. Maka dari itu, penelitian ini bertujuan untuk mengetahui sejauh mana ketrampilan sosial siswa dimasa pandemi. Subyek penelitian merupakan siswa SMA Negeri 1 Kedunggalar, Kabupaten Ngawi dengan responden sebanyak 76 siswa yang dipilih secara acak dari berbagai kelas, jurusan dan jenis kelamin. Penelitian ini merupakan penelitian deskriptif kualitatif. Teknik pengumpulan data mengunakan angket. Analisis data dalam penelitian ini mengacu pada model analisis interaktif yang terdiri dari tahapan reduksi data, penyajian data, dan verifikasi data. Dari penelitian ini nanatinya mampu melihat bagaimana sikap ketrampilan sosial siswa dimasa pandemi.
\end{abstract}

Kata Kunci: Keterampilan sosial, siswa, pandemi

Social, Humanities, and Education Studies (SHEs): Conference Series https://jurnal.uns.ac.id/shes

p-ISSN 2620-9284

e-ISSN 2620-9292 


\section{PENDAHULUAN}

Sejak pada Desember 2019 dunia digemparkan dengan berita penyebaran virus Covid-19 (Coronavirus disease 19) yang sudah menelan banyak korban di Wuhan, China. Sesuai dilansir dalam web covid.cdc.gov total orang yang terinfeksi virus sebanyak 85.337 kasus yang ada di Wuhan dengan total meninggal 4.634 dan sembuh 80.536. Dari awal penyebaran virus yang hanya di Wuhan nampaknya virus juga mulai menyebar keberbagai negara termasuk salah satunya Indonesia. dari cepatnya penyebaran virus tersebut dan belum ditemukan vaksin membuat berbagai negara mengalami krisis kesehatan. WHO organisasi yang menangani kesehatan di dunia mulai membuat berbagai kajian tentang pencegahan penularan covid 19 ini. Anjuran physical distancing, memakai masker, cuci tangan dan menghindari kerumunan menjadi kampanye WHO dan pemerintah diberbagai negara untuk menekan dan mengurangi terinfeksinya Covid-19 ini.

Adanya anjuran terkait hal itu untuk mengurangi penularan virus mengakibatkan berdampaknya disemua lini kehidupan manusia. Dari kesehatan, ekonomi, pendidikan, ibadah dan sebagaianya. Semua terdampak dengan adanya pelarangan untuk menaati anjuran-anjuran tersebut guna mencegah penularan virus. Salah satunya yang berdampak dengan adanya covid-19 ini yaitu di sektor pendidikan. Dunia pendidikan salah satu yang terdampak dengan adanya pandemic covid-19 ini, total sejak bulan maret akhir hamper semua pendidikan formal di Indonesia sudah dianjurkan untuk belajar di rumah, baik dari tingkat TK sampai perguruan tinggi dianjurkan untuk belajar di rumah. Dari anjuran untuk belajar di rumah ini tentunya memiliki berbagai dampak yang muncul dalam proses pembelajaran dan pembentukan afektif dan psikomotorik siswa.

Tidak ada tatap muka secara langsung mengakibatkan siswa secara penuh hanya dapat berinteraksi secara virual baik dengan guru maupun teman-temannya. Hal tersebut mengakibatkan intraksi sosial siswa menjadi berkurang dan juga guru mengalami keterbatasan observasi dan penilaian kemampuan afektif dan psikomotorik siswa. Kondisi sedemikian rupa membuat social skill siswa menjadi tidak berkembang, yang harusnya dapat berinteraksi secara langsung face to face, dikareaakan adanya pandemi siswa hanya dapat interaksi secara sosial media atau virtual. Sebagai guru dan dan tenaga penddikan yang diwajibkan untuk menilai kemampuan siswa secara menyeluruh diharapkan dapat mengatasi permasalahan dalam jalan buntu. Guru bisa tetap membuat terobosan dan inovasi dalam pengembangan kemampuan afektif dan psikomotorik siswa terkhusus kemampuan social skill siswa.

Social skill merupakan kemampuan untuk berinteraksi dengan orang lain dalam satu konteks sosial dengan suatu cara yang spesifik yang secara sosial dapat diterima atau dinilai dan menguntungkan orang lain (Comb dan Slaby, 1977:162). Social skill atau ketrampilan sosial diperlukan oleh siswa untuk hidup dimasyarakat. Widoyoko (2011: 213-214) berpendapat social skill dibutuhkan untuk hidup (life skill) dalam masyarakat yang multikultural, masyakarat demokrasi, dan masyarakat gelobal yang penuh persaingan dan tantangan. Keterampilan sosial meliputi keterampilan berkomunikasi, baik secara lisan maupun tertulis dan kecakapan bekerja sama dengan orang lain, baik dalam kelompok kecil maupun kelompok besar. Sedangkan Golmen (2005:43) membagi social skill menjadi 10 (sepuluh unsur), diantaranya meliputi: pengaruh, komunikasi, kepemimpinan, katalisator perubahan, manajemen konflik, pengikat jaringan, kolaborasi dan kooperasi, dan kemampuan tim.

Social skill menjadi modal yang sangat berharga bagi siswa, dengan keterampilan sosial siswa dapat berinteraksi secara baik di lingkungan masyarakat mereka. Menjaga keterterimaan siswa serta mempertahankan hubungan positif sebagai makhluk sosial di mana mereka berada. Keterampilan sosial dapat diperoleh anak melalui proses sosialisasi dengan lingkungan sekitarnya. Proses sosialisasi merupakan 
proses ketika sang anak mempelajari nilai-nilai dan perilaku yang diterima dari masyarakat (Hildayani dkk, 2011:103).

Pengembangan keterampilan sosial anak bukanlah hal yang mudah dan terbentuk tiba-tiba, sehingga diperlukan adanya usaha dalam memberikan ruang kepada anak untuk membiasakan diri, berlatih dan meningkatkan keterampilan sosial melalui pembelajaran. Namun semua itu berlaku ketika semua kondisi normal, dimana pada saat ini masih sedang berlangsung wabah pandemi covid-19 yang mengakibatkan siswa mengalami keterbatasan berinteraksi sosial. Walaupun pandemi ruang gerak sosial siswa tidak menghilang namun hanya dibatasi, walaupun secara fisik tidak bisa bertatap muka namun dalam media sosial media masih bisa berinteraksi sosial. Namun pertanyaanya bagaimana ketrampilan sosial siswa di masa pandem seperti ini ketika ruang gerak sosial sangat dibatasi, karena notabenenya tidak ada kontak fisik melainkan hanya melalui dunia maya saja.

Berangkat dari berbagai enelitian yang sudah ada, banyak penelitian yang mengkaji tentang keterampilan sosial, sepertihalnya penelitian oleh Muhammad Mushfi (2017) dalam jurnal Pedagogik Universitas Nurul Jadid Probolingo yang mengkaji tentang model interaksi sisial dalam mengelaborasikan ketrampilan sosial. Selanjutnya penelitian Enok Maryani dan Helius Syamsudin (2009) dalam jurnal Penelitian dengan kajian Pengembanagan Program Pembelajaran IPS untuk Meningkatkan Kompetensi Ketrampilan Sosial. Ada pula juga dari Clara Dewanti, dkk (2016) yang megkaji tentang hubungan antara keterampilan sosial dan penggunaan gadget smartphone terhadap prestasi belajar siswa SMA Negeri 9 Malang, yang diterbitkan dalam Jurnal Kajian Bimbingan dan Konseling. Kemudian penelitian dari Rini Sugiarti \& Agung Santoso P. (2013) juga mengkaji tentang perbedaan penerapan model pembelajaran kooperatif tipe numbered head together (nht) dan jigsaw terhadap peningkatan keterampilan sosial pada siswa SMA (studi kasus di SMA Karangturi Semarang), penelitian tersebut diterbitkan dalam jurnal Wacana.

Dari berbagai kajian tersebut menjadi rujukan bagi peneliti untuk bergerak melakukan penelitian ini, namun dari kesekian kejian tersebut berjalan dimasa kondisi normal. Berbeda dengan sekarang, kondisi pandemic mengakibatkan pembelajar berjalan secara daring dan kekiatan interaksi sosial siswa sangat berkurang. Maka dari itu peneliti berkeinginan mengakia bagaimana dampak pandemi yang meajibkan siswa belajar secara daring namun juga masihmemiliki keterampilan sosial.

\section{METODE}

Penelitian ini bersifat deskriptif kualitatif. Subyek penelitian merupakan siswa SMA Negeri 1 Kedunggalar. Responden penelitian sebanyak 76 siswa yang dipilih secara acak (random sampling). Teknik pengumpulan data berupa angket yangbersifat terbuka dengan skala likert. Responden mengisi pilihan yang telah disediakan memalui google form dengan 7 butir pertanyaan. Dari hasil angket tersebut kemudian dihimpun dan dianalsisi serta ditarik kesimpulan disetiap butir pertanyaan sesuai indikator.

\section{HASIL DAN PEBAHASAN}

Sebagai upaya menghambat penularan covid-19 kementrian pendidikan dan kebudayaan Indonesia menganjurkan untuk semua sekolah melakukan pembelajaran secara daring. Kondisi ini tentu mengakibatkan banyak dampak bagi sistem pendidikan di Indonesia. Terutama yang terdampak adalah para siswa dan guru. Guru dituntut dapat tetap menyampaikan materi dengan pemanfaatan media dan siswa diharapkan menikuti materi yang disampaikan oleh guru melalui platform media daring yang digunakan. Perubahan model pembelajaran secara derastis seperti ini membuat culture syok bagi 
siswa dan guru. Namun dalam perubahan model pembelajaran ini yang paling berdampak yaitu siswa. Mengutip tulisan Rizqon Halal S. A. (2020) pembelajarn daring berdampak terhadap psikologis dan ketrampilan siswa. Proses pembentukan ketrampilan siswa mengalami penghambatan karena interaksi sosial hanya bisa melalui sosial media tanpa ada kontak fisik. Sedangkan ketrampilan sosial sangat dibutuhkan oleh siswa untuk bergaul di masyarakat. Walaupun dalam pembelajaran daring di masa pamdemi seperti ini apakah siswa masih dapat mengembangkan keterampilan sosial mereka, melihat tidak ada aktifitas interaksi sosial seperti biasanya di sekolahan. Hal tersebut menjadi menarik untuk ditelusuri dan dibahas. Berikut data-data ulasan terkait keterampilan siswa di masa pandemic covid 19:

Tabel 1. Hasil Angket Siswa Terkait Tanggapain Pembeelajaran daring \& Ketrampilan Sosial di Media Sosial

\begin{tabular}{|c|c|c|c|c|c|c|}
\hline \multirow{2}{*}{ No } & \multirow{2}{*}{ Pernyataan } & \multicolumn{5}{|c|}{ Hasil Pendapat (\%) } \\
\hline & & SS & $\mathbf{S}$ & B & $\mathrm{Sd} / \mathrm{J}$ & SJ/SS \\
\hline 1 & Kesan Pembelajaran Daring & 3,9 & 22,4 & 36,8 & 23,7 & 13,2 \\
\hline 2 & Penggunaan Group Media Sosial & 26,3 & 43,4 & 11,8 & 13,2 & 5,3 \\
\hline 3 & $\begin{array}{l}\text { Mengemukakan Pendapat di forum / group } \\
\text { sosial media }\end{array}$ & 1,3 & 25 & 34,2 & 31,6 & 7,9 \\
\hline 4 & Memuji Orang Lain & 7,9 & 32,9 & 28,9 & 27,6 & 2,6 \\
\hline 5 & Menawarkan Bantuan & 5,3 & 42,1 & 31,6 & 18,4 & 2,6 \\
\hline 6 & Menasehatai Teman / Orang Lain & 11,8 & 22,4 & 31,6 & 32,9 & 1,3 \\
\hline 7 & $\begin{array}{lll}\text { Bertengkar } & \text { dengan } & \text { Teman } \\
\text { Orang Lain } & & \\
\end{array}$ & & 9,2 & 47,4 & 25 & 18,4 \\
\hline
\end{tabular}

Keterangan:

SS : Sangat Senang / Sangat Sering

S : : Senang / Sering

B : : Biasa Saja

J : : Jarang

Sd : Sedih

SS : Sangat Sedih

SJ : Sangat Jarang

\section{Pembelajaran Daring}

Dari data table 1 di atas menunjukan mayoritas siswa menangapi "Biasa saja" dalam situasi pembelajaran darig. Total 28 responden atau 36,8\% dari total 76 siswa menanggapi biasa saja dalam pembelajaran daring di masa pandemic ini. Selain itu terdapat pula siswa yang merasa senang menjalani kondisi pembelajaran daring, sebanyak 17 responden atau $22,4 \%$ siswa senang dengan adanya pembelajaran daring dan 3 responden atau 3,9 siswa merasa sangat senang dengan pembelajaran daring. Ada pula siswa yang merasa sedih dengan adanya pemebalajan daring, sebanyak 18 responden atau $23,7 \%$ menyatakan sedih dan 10 responden atau 13,2 menyatakan sangat sedih dengan adanya pembelajaran daring.

Tentunya dengan adanya pembelajaran daring ini memunculkan berbagai tanggapan oleh siswa, mungkin akan menemukan tanggapan yang berbeda terkait pembelajaran daring. Tanggapan siswa dapat dipengaruhi juga dengan kondisi lingkungan dan fasilitas pendukung untuk melakukan pembelajaran daring. Seperti hasil penelitian oleh Bobby Briando yang mengkaji persepsi siswa pembelajaran online di 
masa pandemi di SMAN 4 Tanjungpinang. Dari penelitian tersebut menunjukan temuan data mayoritas siswa memberi jawaban netral terkait pembelajaran daring di masa pandemi. Dari total responden 180 siswa, sebanyak 92 atau $50.1 \%$ menjawab netral terkait pembelajaran daring. Hal tersebut selaras dengan temuan data oleh peneliti. Bisa saja dan netral merupakan sama-sama titik tengah dalam angket yang ditujukan oleh responden (siswa). Dengan demikian dapat ditarik kesimpulan bahwasanya siswa memiliti tanggapan biasa saja atau netral terkait pembelajaran daring di masa pandemi covid-19.

\section{Penggunaan Group di Sosial Media}

Kondisi pandemi covid-19 tidak menjadi penghambat siswa untuk berinteraksi sosial dengan teman sebaya karena masih terfasilitasi dengan teknologi komunikasi, apalagi sosial media sangat mewadahi kegiatan interaksi sosial. Menurut Prabowo dan Faridah Nurmaliah (2013:202) salah satu indikator keterampilan sosial adalah kecakapan berkomunikasi. Sedangkan indicator kecakapan berkomunikasi memiliki indikator lagi antara lain: 1) kemampuan mendengar dengan empati; 2) kemampuan menyampaikan gagasan dengan empati; 3) kecakapan berkomunikasi dengan teknologi; 4) kemampuan meyakinkan orang lain; dan 5) keberanian mengemukakan pendapat.

Untuk mengetahui kecakapan berkomunikasi kita dapat melihat table 1 tentang penggunaan group di sosial media, dari table tersebut menunjuka mayoritas siswa sering menggunakan group di sosial media. Sebanyak 33 responden atau 43,4\% siswa menyatakan sering menggunakan sisal media dan 20 siswa atau 26,3\% menyatakan sangat sering. Sedangkan 10 siswa atau $13,2 \%$ siswa menyatakan jarang menggunakan group sosial media dan 4 siswa atau 5,3\% menyatakan sangat jarang. Selanjutnya hanya 9 siswa atau $11,8 \%$ menjawab biasa saja. Dari total responden 76 siswa mayoritas siswa masih memiliki kemampuan keterampilan sosial dengan indikator kecakapan berkomunikasi dengan teknologi.

\section{Mengemukakan Pendapat di Forum / Group Sosial Media}

Berani mengemukakan pendapat termasuk dalam kecakapan berkomunikasi yang merupakan salah satu dari indikator keterampilan sosial (Prabowo dan Faridah Nurmaliah, 2013:202). Masa pandemic covid-19 ini tidak menghalangi pembentuka forum-forum rapat atau diskusi dikarenakan teknologi komunikasi berupa sosial media sudah sangat mewadahi untuk saling bertukar pesan baik pesan teks, suara, gambar, video, bahkan video call.

Seberpa jauh siswa dalam keberanian megemukakan pendapat dalam forum di sosial media dapat dilihat dari data tabl 1 di atas. Dari data tersebut menunjukan bahwa dari total 76 responden, mayoritas siswa menyatakan biasa saja, sebanyak 26 atau $34,2 \%$ siswa berpendapat biasa saja dalam mengemukakan pendapat di forum di sosial media. Sedangkan 19 siswa atau 25\% menyatakan sering dan 1 siswa atau 1,3\%, 24 siswa atau 31,6 jarang serta 6 siswa atau 7,9\% menyatakan sangat jarang. Dari data tersebut dapat disimpulkan bahwa kecakapan berkominikasi dalam bidang keberanian mengemukakan pendapat tergolong sedang.

\section{Memuji Orang Lain}

Caldarella dan Merrell (dalam Gimpel \& Merrell, 1998) berpendapat terdapat 5 (lima) dimensi dalam keterampilan sosial, yaitu: 1) Hubungan dengan teman sebaya (Peer relation), ditunjukkan melalui perilaku yang positif terhadap teman sebaya seperti memuji atau menasehati orang lain, menawarkan bantuan kepada orang lain, dan bermain bersama orang lain; 2) Manajemen diri (Self-management), merefleksikan 
remaja yang memiliki emosional yang baik, yang mampu untuk mengontrol emosinya, mengikuti peraturan dan batasan-batasan yang ada, dapat menerima kritikan dengan baik; 3) Kemampuan akademis (Academic), ditunjukkan melalui pemenuhan tugas secara mandiri, menyelesaikan tugas individual, menjalankan arahan guru dengan baik; 4) Kepatuhan (Compliance), menunjukkan remaja yang dapat mengikuti peraturan dan harapan, menggunakan waktu dengan baik, dan membagikan sesuatu; 5) Perilaku assertive (Assertion), didominasi oleh kemampuan kemampuan yang membuat seorang remaja dapat menampilkan perilaku yang tepat dalam situasi yang diharapkan.

Merujuk pendapat tersebut perilaku memuji masuk katogiri peer relation atau hubungan baik dengan teman sebaya yang merupakan salah satu indikator dari keterampilan sosial. Adanya sosial media yang berkembang saat ini komunikasi antar teman sebaya menjadi sangat mudah, bahakan kita juga bisa mengetahui berbagai kegiatan teman dari sosial media mereka, terkadang pula dijumpai hal-hal yang bagus dan menarik yang mengakibatkan mendapat pujian dari orang lain. Untuk mengetahui bagaimana kemampuan peer relation siswa dari perilaku memuji orang lain dapat kita lihat dari data table $1 \mathrm{di}$ atas.

Dari total 76 responden, sebanayak 15 responden atau $32,9 \%$ siswa sering memuji orang lain dan 6 responden atau $7,9 \%$ perpendapat sangat sering. Perilaku ini merupakan hal yang positif. Sedangkan 22 responden atau $28,9 \%$ menyatakan biasa saja. Kemudian 21 responden atau 27,6\% menyatakan jarang serta 2 responden atau $2,6 \%$ siswa menyatakan sangat jarang. Dari sajian data tersebut dapat disimpulkan bahwa kemampuan siswa membangun hubungan baik (peer relation) dari perilaku memuji orang lain sangat baik.

\section{Menawarkan Bantuan}

Masih dalam indikator peer relation, keterampilan sosial salah satunya membangun hubungan baik dengan teman sebaya dengan cara berperilaku menawarkan bantuan terhadap teman. Sesuai pendapat Gimpel dan Merrell dapat kita lihat bagamana kemampuan keterampilan sosial siswa dari hubungan baik dengan teman sebaya dalam perilaku menawarkan bantuan terhadap orang lain. Untuk mengetahui hal tersebut dapat kita lihat data pada table 1 di atas. Sebanyak 32 responden atau 42,1 siswa menyatakan sering menawarkan bantuan kepada teman sebaya dan 4 responden atau 5,3\% siswa menyatakan sangat sering. Kemudian sebagain kecil 14 responden atau 18,4\% menyatakan jarang menawarkan bantuan terhadap orang lain dan 2 responden atau $2,6 \%$ menyatakan sangat jarang. Selebihnya hanya 24 responden atau $31,6 \%$ siswa menyatakan biasa saja. Dari data tersebut menunjukan perilaku peer relation siswa tergolong cukup bagus dan dapat dikatakan memiliki keterampilan sosial juga cukup bagus.

\section{Menasehati Orang Lain}

Masih tergolong dalam membangun hubungan baik dengan teman sebaya, menasehati orang lain juga masuk kategori peer relation, yang mana merupakan salah satu indikator dari keterampilan sosial menurut pendapat Gimpel dan Merrell. Memiliki kemampuan menasehati orang lain sama halnya memiliki keterampilan sosial yang baik. Untuk melihat bagaimana kemampuan siswa dalam menasehati orang lain dapat dilihat pada tabel 1 di atas.

Dari total 76 responden, sebanyak 25 responden atau 32,9\% siswa menanggapi jarang dan 1 responden atau 1,3\% siswa menyatakan sangat jarang. Sedangkan 17 responden atau 22,4\% siswa menyatakan sering dan 9 responden atau $11,8 \%$ siswa menyatakan sangat sering. Selebihnya 24 resonden atau $31,6 \%$ siswa menyatakan biasa saja. Dari data berikut menunjukan bahwa kemampuan menasehati orang lain 
masih tergolong biasa cenderung rendah. Hal ini menjadi salah satu indikator dari keterampilan sosial siswa.

\section{Bertengkar dengan Orang Lain}

Sesuai pendapat Gimpel dan Merrell, bertengkat dengan orang lain termasuk bertolak belakang dengan indikator keterampilan sosial siswa. Bertengkar dengan orang lain merupakan keterbalikan dari peer relation dan self-management yang merupakan salah satu indikator keterampilan sosial. Untuk melihat sejauh mana siswa memiliki kemampuan peer relation dan self-management dengan baik yang berdampak memiliki kemungkinan bertengkar dengan orang lain kecil, maka dapat kita lihat datapada tabel 1 di atas.

Dari total 76 responden, mayoritas pernah bertengkar dengan teman sebanyak 36 responden atau 47,4\% siswa menyatakan pernah bertengkar dengan siswa dan 7 responden atau 9,2\% siswa menyatakan sering bertengkar dengan temannya. Sedangkan 14 reponden atau 18,4\% menyatakan tidak pernah berengkar dengan teman. Selebihnya ada 19 responden atau 25\% menyatakan jarang bertengkar dengan temannya. Dari data tersebut menunjukan bahwasanya kemampuan peer relation dan self-management cukup baik dikarenakan kecenderungan bertengkar dengan teman cukup kecil, walaupun mayoritas menyatakan pernah namun tidak sering terjadi.

\section{SIMPULAN}

Adanya pandemi covid-19 yang mengakibatkan pembelajarn dikelas dialihkan secara daring serta adanya kebijakan physical distancing sehingga interaksi sosial siswa secara langsung dengan teman sebanyanya berkuran. Namun dalam pembentukan keterampilan sosial masih tetap bisa berjalan karena interaksi sosial masih bisa terjalin melalui aplikasi sosial media. Maka dari itu tidak ada alasan siswa untuk tetap tidak belajar dan tidak meningkatkan keterampilan sosial guna bekal mereka hidup bermasyarakat.

\section{DAFTAR PUSTAKA}

Briando, Bobby (2020) Persepsi Siswa Terhadap Pembelajaran Online di Masa Pandemi pada Sekolah Menengah Atas Negeri Empat Tanjungpinang, Prosiding dalam Webinar \& Call Papers, Universitas Negeri Malang

Comb dan Slaby (1977). Social Skills Training With Children. New York:Plenum Press

Dewanti, Clara, T., et all. (2016) Hubungan Antara Keterampilan Sosial dan Penggunaan Gadget Smartphone Terhadap Prestasi Belajar Siswa SMA Negeri 9 Malang. Jurnal Kajian Bimbingan dan Konseling, 1 (3) 126-131

Gimpel, G. A., \& Merrel, K. W. 1998. Social Skills of Children and Adolescents: Conceptualization, Assessment, Treatment. Mahwah, NJ: Erlbaum

Goleman, Daniel. (2005). Working with Emotional Inteligence (Kecerdasan Emosiuntuk Mencapai Puncak Prestasi). Jakarta: PT Gramedia Pustaka Utama

Halal, Risqon, S. A. (2020) Dampak Covid 19 pada Pendidikn di Indonesia: Sekolah, Keterampilan, dan Proses Pembelajaran, SALAM: Jurnal Sosial \& Budaya Syar'l, 7 (5) 395-402

Hildayani, Rini, Dkk. (2013). Psikologi Perkembangan Anak. Jakarta: Universitas Terbuka

Maryani, E., \& Syamsudin, H. (2009) Pengembanagan Program Pembelajaran IPS untuk Meningkatkan Kompetensi Ketrampilan Sosial. Jurnal Penelitian, 9 (1) 1-15

Merrell, K.W. 2003. Behavioral, social, and emotional assessment of children and adolescents. New Jersey: Lawrence Erlbaum Associates 
Mushfi, Muhammad. (2017) Model Interaksi Sosial dalam Mengelaborasi Keterampilan Sosial, Jurnal Pedagogik, 4 (2) 211-227

Prabowo, Sugeng Listyo, dan Nurmaliyah Faridah. 2013. Perencanaan Pembelajaran pada Bidang Studi Tematik, Muatan Lokal, Kecakapan Hidup, Bimbingan dan Konseling. Malang: UIN Maliki Press

Sugiarti, Rini \& Santoso, Agung, P. (2013) Penerapan Model Pembelajaran Kooperatif Tipe Numbered Head Together (NHT) dan Jigsaw Terhadap Peningkatan Keterampilan Sosial pada Siswa SMA (Studi Kasus di SMA Karangturi Semarang), Jurnal Wacana, 5 (2) 1-15

Widoyoko, Eko Putro. (2011). Evaluasi Program Pembelajaran Panduan Praktis bagi Pendidik dan Calon Pendidik. Yogyakarta: Pustaka Pelajar 